\title{
Factors Associated with SARS-CoV-2 Infection among Oral Health Team Professionals
}

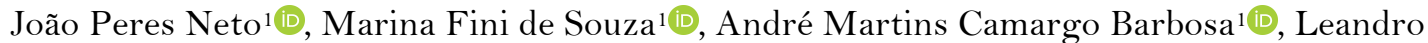
Loschiavo Marsico $^{1}\left[\begin{array}{l}\text {, Wander Barbieri1 } \\ 1\end{array}\right.$

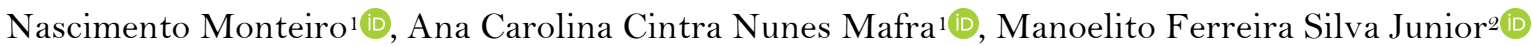

'Albert Einstein Israeli Hospital, São Paulo, SP, Brazil.

${ }^{2}$ Department of Dentistry, Ponta Grossa State University, Ponta Grossa, PR, Brazil.

Correspondence: João Peres Neto, Rua Almaden, 130, Vila Andrade, São Paulo, SP, Brazil. 05717-200. E-mail: jperesnetode@yahoo.com.br

Academic Editor: Alessandro Leite Cavalcanti

Received: 01 May 2021 / Review: 11 June 2021 / Accepted: 13 July 2021

How to cite: Peres Neto J, Souza MF, Barbosa AMC, Marsico LL, Barbieri W, Palacio DC, et al. Factors associated with SARS-CoV-2 infection among oral health team professionals. Pesqui Bras Odontopediatria Clín Integr. $2021 ; 21$ :e0089. https://doi.org/10.1590/pboci.2021.164

\footnotetext{
ABSTRACT

Objective: To analyze the factors associated with the SARS-CoV-2 infection among oral health professionals. Material and Methods: This was a cross-sectional study in the city of São Paulo, São Paulo State, Brazil. Professionals from three different categories were included: dental surgeons (DS), dental assistants (DA), and dental hygienists (DH). A questionnaire was created on a digital platform and sent via institutional email to each subject. The questionnaire contained 32 questions about sociodemographic, work, and behavior factors. The data about SARS-CoV-2 infection was confirmed through RT-PCR exams. Descriptive (absolute and relative frequencies) and inferential analyses (chi-squared or Fisher's exact test) $(\mathrm{p}<0.05)$ were performed. Results: There was a SARS-CoV-2 infection prevalence of $3.8 \%$ for DS, $30.0 \%$ for $\mathrm{DH}$, and $33.3 \%$ for DA. SARS-CoV-2 was associated with a lower income $(\mathrm{p}=0.027)$, a lower education level $(\mathrm{p}=0.011)$, the category of technical professionals $(\mathrm{DA}$ and $\mathrm{DH})(\mathrm{p}=0.025)$, and using public transportation to commute to work $(\mathrm{p}=0.009)$. Conclusion: Sociodemographic factors like lower income and education levels and work factors like job category and public transportation were associated with COVID-19 among professionals on the oral health teams.

Keywords: COVID-19; SARS-CoV-2; Oral Health; Primary Health Care.
} 


\section{Introduction}

SARS-CoV-2, the virus discovered in December 2019 in Wuhan, China, is the pathogen responsible for the Coronavirus Disease of 2019 (COVID-19). In March 2020, COVID-19 was categorized by the World Health Organization as the pandemic with the largest impact in the current century. It has introduced challenges to the routines of health professionals [1,2].

As the respiratory tract is the principal form of infection by SARS-CoV-2, the risk of transmission becomes extremely high in clinical dental practice. Besides close contact between the professional and the patient, the routine work process includes the use of equipment that disperses aerosols of potentially contaminated body fluids into the environment [3-7].

Hence, strict biosafety recommendations were published during the pandemic [8,9], including the suspension of elective services, avoiding the use of devices that generate aerosols, a strict use of personal protection equipment (PPE) and the inclusion of additional protection, such as N95/NFFP/or similar masks and face shields [4-6]. However, besides the clinical occupational risk, socioeconomic factors can increase the risk of SARS-CoV-2 infection and deserve greater attention [10].

Studies about SARS-CoV-2 infection in odontology [4,6,7] have been directed at dental surgeons (DS), and little is known about the realities of dental hygienists (DH) and dental assistants (DA), mainly working in essential services such as primary health care (PHC). Hence, the objective of this study was to analyze the prevalence of and the factors associated with the SARS-CoV-2 disease among oral health teams (OHT) in the public dental health system in 2020.

\section{Material and Methods}

\section{Study Design}

A cross-sectional web survey was conducted in September 2020 with OHT professionals at Clinics I and II of the 11 public health clinics (HC) under the responsibility of the Brazilian Israeli Charitable Society Albert Einstein Hospital (Sociedade Beneficente Israelita Brasileira Hospital Albert Einstein), in the south zone of the city of São Paulo, SP, Brazil.

\section{Sample and Data Collection}

Dental surgeons (DS), dental assistants (DA), and dental hygienists (DH) were included in the study. Those who were on leave during the data-gathering period of the study were excluded.

A questionnaire was created on a digital platform and sent via institutional email to each subject in the sample, obtained from the human resources department. The questionnaire contained 32 questions about sociodemographic, work, and behavior factors. The data about SARS-CoV-2 infection was confirmed through RT-PCR exams.

The dependent variable of the study was the diagnosis of SARS-CoV-2 infection, dichotomized into: "confirmed" and "unconfirmed". The independent variables were divided into three categories:

1. Sociodemographic: sex (male or female); age (in years); education level (high school/technical school or college/post-graduate); household income (determined by the median income); relation of the number of inhabitants per room (less than 1, or greater than or equal to 1); comorbidities (yes or no); and having a relative diagnosed with COVID-19 (yes or no).

2. Work: job category (DS, DA, or DH); private (car, bicycle, on foot) or public (bus, metro, train) method of transportation used to commute and the commute time (up to 1 hour or over 1 hour); PPE availability and quality. 
3. Behavior: safety (yes or no); fear of infection (yes or no); feels informed about COVID-19 (yes or no); sources of information (institutional, TV, internet, others).

Data Analysis

The data was analyzed using IBM SPSS Statistics for Windows, Version 21.0 (IBM Corp., Armonk, NY, USA). Descriptive (absolute and relative frequencies) and inferential analyses (chi-squared or Fisher's exact test) $(\mathrm{p}<0.05)$ were performed.

\section{Ethical Clearance}

The study was approved by the Committee of Ethics in Research of the Municipal Health Secretariat of São Paulo (Protocol No. 4.363.698).

\section{Results}

Sixty-four (64) oral health professionals participated in the study, with a response rate of $77.1 \%$. The majority of the participants were women $(84.4 \%), \leq 44$ years old $(60.9 \%)$, white $(51.6 \%)$, bachelor's degree or higher $(50.0 \%)$, monthly salary of $\leq$ BRL $\$ 5,000(54.7 \%)$ and an average of $<1$ inhabitant per room $(78.9 \%)$.

The general prevalence of SARS-CoV-2 infection was $20.3 \%$ and by job category, DS (3.8\%), DH (30.0\%), and DA (33.3\%). In addition, SARS-CoV-2 infection was associated with professionals with a lower education level $(p=0.011)$ and lower salary level $(p=0.027)$ (Table 1).

Table 1. Sociodemographic factors associated with SARS-CoV-2 infection among oral health team professionals.

\begin{tabular}{|c|c|c|c|c|c|c|c|}
\hline \multicolumn{8}{|c|}{ COVID-19 } \\
\hline \multirow[t]{2}{*}{ Variables } & \multicolumn{2}{|c|}{ No } & \multicolumn{2}{|c|}{ Yes } & \multicolumn{2}{|c|}{ Total } & \multirow[t]{2}{*}{ p-value } \\
\hline & $\mathrm{N}$ & $\%$ & $\mathrm{~N}$ & $\%$ & $\mathrm{~N}$ & $\%$ & \\
\hline \multicolumn{8}{|l|}{ Sex } \\
\hline Male & 8 & 80.0 & 2 & 20.0 & 10 & 15.6 & 0.979 \\
\hline Female & 43 & 79.6 & 11 & 20.4 & 54 & 84.4 & \\
\hline \multicolumn{8}{|l|}{ Age } \\
\hline$\leq 44$ years old & 39 & 78.0 & 11 & 22.0 & 39 & 60.9 & $0.715^{*}$ \\
\hline$\geq 45$ years old & 12 & 85.7 & 2 & 14.3 & 12 & 18.8 & \\
\hline \multicolumn{8}{|l|}{ Race } \\
\hline White & 29 & 87.9 & 4 & 12.1 & 33 & 51.6 & $0.124 *$ \\
\hline Other (Black, Brown and Asian) & 22 & 71.0 & 9 & 29.0 & 31 & 48.4 & \\
\hline \multicolumn{8}{|l|}{ Education } \\
\hline High school / Technical school & 21 & 65.6 & 11 & 34.4 & 32 & 50.0 & $0.011^{*}$ \\
\hline Bachelor's / Post-graduate & 30 & 93.8 & 2 & 6.2 & 32 & 50.0 & \\
\hline \multicolumn{8}{|l|}{ Monthly Income (BRL) } \\
\hline$\leq 5,000$ & 24 & 68.6 & 11 & 31.4 & 35 & 54.7 & $0.027^{*}$ \\
\hline$>5,000$ & 27 & 93.1 & 2 & 6.9 & 29 & 45.3 & \\
\hline \multicolumn{8}{|l|}{ Number of Inhabitants per room } \\
\hline$<1$ & 44 & 80.0 & 1 & 20.0 & 45 & 78.9 & $0.665^{*}$ \\
\hline$\geq 1$ & 6 & 75.0 & 6 & 25.0 & 12 & 21.1 & \\
\hline \multicolumn{8}{|l|}{ Comorbidities } \\
\hline No & 44 & 80.0 & 11 & 20.0 & 55 & 85.9 & $0.999^{*}$ \\
\hline Yes & 7 & 77.8 & 2 & 22.2 & 9 & 14.1 & \\
\hline \multicolumn{8}{|l|}{ Relative with COVID-19 } \\
\hline No & 44 & 83.0 & 9 & 17.0 & 53 & 82.8 & $0.213^{*}$ \\
\hline Yes & 7 & 63.6 & 4 & 36.4 & 11 & 17.2 & \\
\hline
\end{tabular}

*Fisher's exact test $(\mathrm{p}<0.05)$. 
Most participants were were dental surgeons (40.6\%), used private transportation to go to work $(64.1 \%)$, and commuted for up to 1 hour $(62.5 \%)$. During the pandemic, the professionals were not reallocated to another service $(84.4 \%)$, nor did they change their duties $(70.3 \%)$. They did not feel safe to carry out their job $(51.6 \%)$ and were afraid of SARS-CoV-2 infection (85.9\%). In relation to the information about COVID-19, 96.9\% felt informed, $92.2 \%$ received information from the institution, and $98.4 \%$ took one or more e-learning courses about COVID-19. SARS-CoV-2 infection was associated with DAs and DHs ( $\mathrm{p}=0.025)$, the use of public transportation to commute to work $(\mathrm{p}=0.009)$, and no access to information on the internet $(\mathrm{p}=0.027)$ (Table 2).

Table 2. Work and behavior factors associated with SARS-CoV-2 infection among oral health team professionals.

\begin{tabular}{|c|c|c|c|c|c|c|c|}
\hline \multicolumn{8}{|c|}{ COVID-19 } \\
\hline \multirow[t]{2}{*}{ Variables } & \multicolumn{2}{|c|}{ No } & \multicolumn{2}{|c|}{ Yes } & \multicolumn{2}{|c|}{ Total } & \multirow[t]{2}{*}{ p-value } \\
\hline & $\mathrm{N}$ & $\%$ & $\mathrm{~N}$ & $\%$ & $\mathrm{~N}$ & $\%$ & \\
\hline \multicolumn{8}{|l|}{ Job Category } \\
\hline $\mathrm{DS}$ & 25 & 96.2 & 1 & 3.8 & 26 & 40.6 & \\
\hline $\mathrm{DA}$ & 12 & 66.7 & 6 & 33.3 & 18 & 28.1 & \\
\hline $\mathrm{DH}$ & 14 & 70.0 & 6 & 30.0 & 20 & 31.3 & \\
\hline \multicolumn{8}{|c|}{ Transportation Method to Commute to Work } \\
\hline Private (car, bicycle, on foot) & 37 & 90.2 & 4 & 9.8 & 41 & 64.1 & $0.009^{*}$ \\
\hline Public (bus, metro, train) & 14 & 60.9 & 9 & 39.1 & 23 & 35.9 & \\
\hline \multicolumn{8}{|l|}{ Commute Time to Work } \\
\hline Up to $1 \mathrm{~h}$ & 34 & 85.0 & 6 & 15.0 & 40 & 62.5 & 0.173 \\
\hline Over $1 \mathrm{~h}$ & 17 & 70.8 & 7 & 29.2 & 24 & 37.5 & \\
\hline \multicolumn{8}{|l|}{ Reallocated to Another Service } \\
\hline No & 43 & 79.6 & 11 & 20.4 & 54 & 84.4 & 0.999* \\
\hline Yes & 8 & 80.0 & 2 & 20.0 & 10 & 15.6 & \\
\hline \multicolumn{8}{|l|}{ Changed Job Duties } \\
\hline No & 36 & 80.0 & 9 & 20.0 & 45 & 70.3 & 0.999* \\
\hline Yes & 15 & 78.9 & 4 & 21.2 & 19 & 29.7 & \\
\hline \multicolumn{8}{|l|}{ Felt Safe Carrying out Their Job } \\
\hline No & 26 & 78.8 & 7 & 21.2 & 33 & 51.6 & 0.854 \\
\hline Yes & 25 & 80.6 & 6 & 19.4 & 31 & 48.4 & \\
\hline \multicolumn{8}{|l|}{ Afraid of Infection } \\
\hline No & 8 & 88.9 & 1 & 11.1 & 9 & 14.1 & $0.672^{*}$ \\
\hline Yes & 43 & 78.2 & 12 & 21.8 & 55 & 85.9 & \\
\hline \multicolumn{8}{|l|}{ Felt informed about COVID-19 } \\
\hline No & 1 & 50.0 & 1 & 50.0 & 2 & 3.1 & $0.368^{*}$ \\
\hline Yes & 50 & 80.6 & 12 & 19.4 & 62 & 96.9 & \\
\hline \multicolumn{8}{|l|}{ Information from the Company } \\
\hline No & 4 & 80.0 & 1 & 20.0 & 5 & 7.8 & 0.999* \\
\hline Yes & 47 & 79.7 & 12 & 20.3 & 59 & 92.2 & \\
\hline \multicolumn{8}{|l|}{ Information from the $\mathrm{TV}$} \\
\hline No & 4 & 66.7 & 2 & 33.3 & 6 & 9.4 & $0.593^{*}$ \\
\hline Yes & 47 & 81.0 & 11 & 19.0 & 58 & 90.6 & \\
\hline \multicolumn{8}{|l|}{ Information from the Internet } \\
\hline No & 3 & 42.9 & 4 & 57.1 & 7 & 10.9 & $0.027^{*}$ \\
\hline Yes & 48 & 84.2 & 9 & 15.8 & 57 & 89.1 & \\
\hline \multicolumn{8}{|l|}{ Information from Other Sources } \\
\hline No & 46 & 79.3 & 12 & 20.7 & 58 & 90.6 & 0.999* \\
\hline Yes & 5 & 83.3 & 1 & 16.7 & 6 & 9.4 & \\
\hline \multicolumn{8}{|l|}{ Took an e-learning Course } \\
\hline No & 1 & 100.0 & $\mathrm{O}$ & 0.0 & 1 & 1.6 & 0.999* \\
\hline 1 or more courses & 50 & 79.4 & 13 & 20.6 & 63 & 98.4 & \\
\hline \multicolumn{8}{|l|}{ Took an in-person Course } \\
\hline No & 17 & 77.3 & 5 & 22.7 & 22 & 34.4 & 0.728 \\
\hline 1 or more courses & 34 & 81.0 & 8 & 19.0 & 42 & 65.6 & \\
\hline
\end{tabular}

*Fisher's exact test $(\mathrm{p}<0.05)$. 
PPE was made available by the employer for more than $80.0 \%$ of all the OHT professionals surveyed. Hair nets, glasses, and disposable gowns were the most available PPE, and face shields (15.9\%) were the least available (Figure 1).

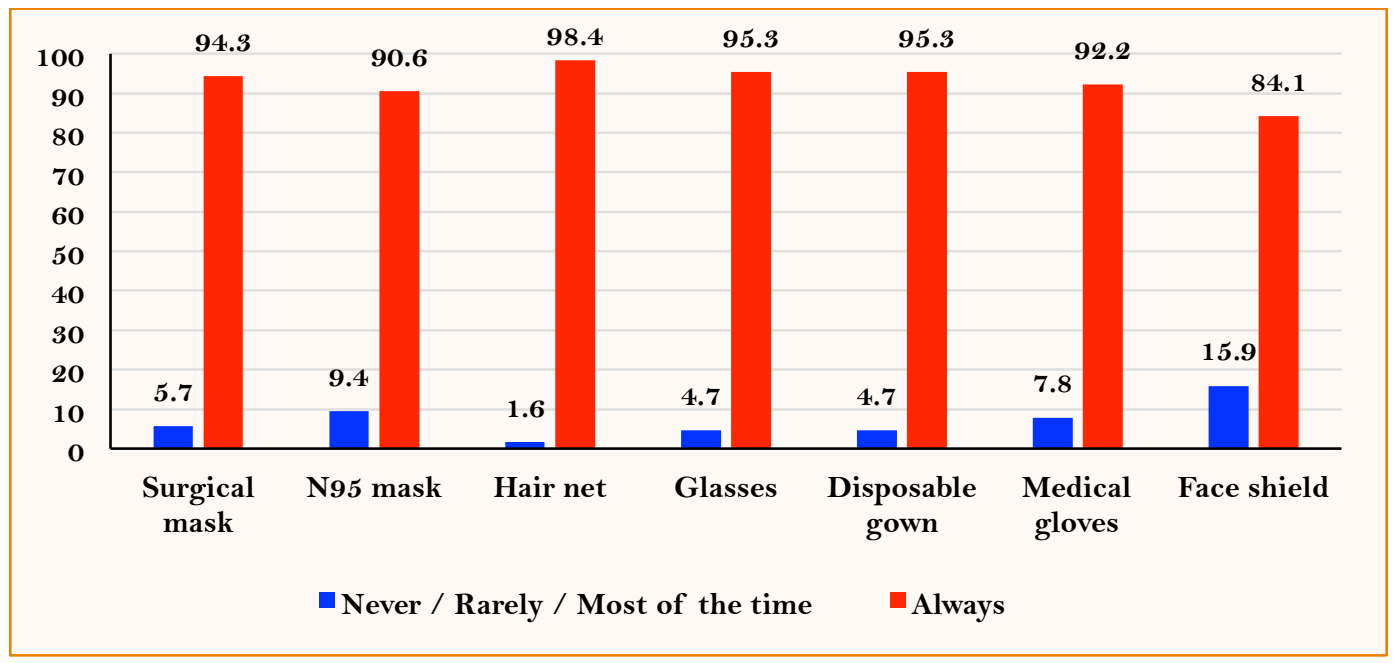

Figure 1. Distribution of the availability of personal protection equipment (PPE) for oral health team professionals. São Paulo-SP, 2020.

Regarding the condition/quality of the PPE, glasses were the highest rated (100.0\%) and face shields were the lowest rated (30.5\%) (Figure 2$)$.

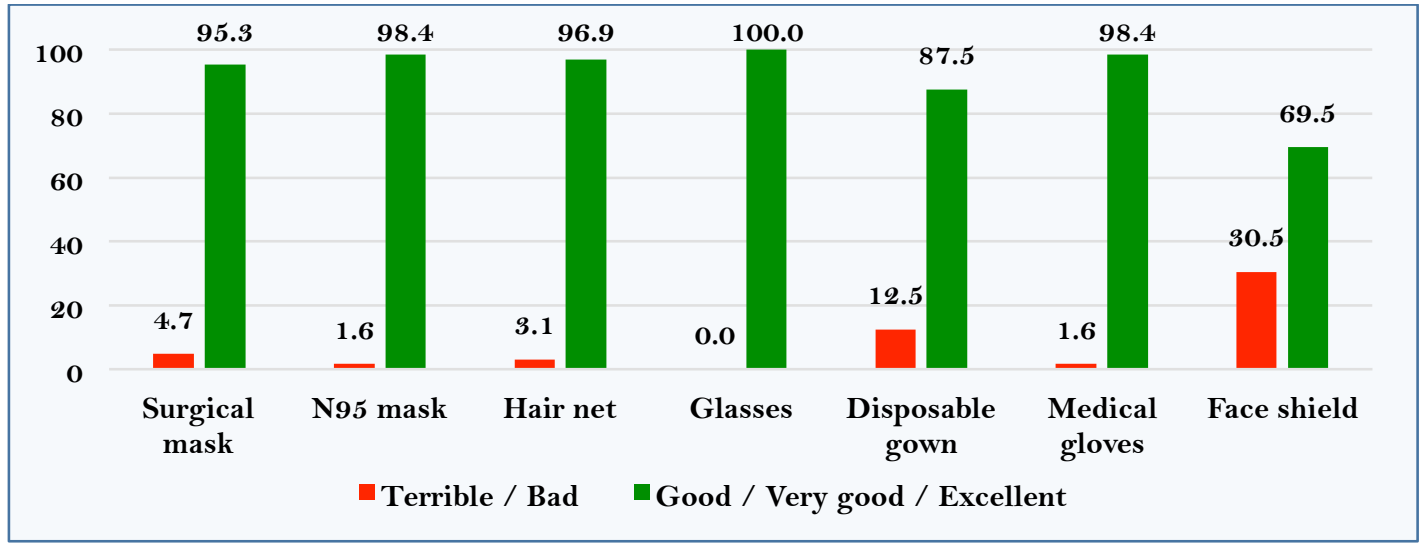

Figure 2. Distribution of the condition/quality of personal protection equipment (PPE) available to the oral health team professionals.

\section{Discussion}

The prevalence of SARS-CoV-2 infection among oral health professionals was high, and well above the general population [11,12], and produced results that were discrepant with studies done with DSs in Italy $(0.25 \%)$ [13] and the United States (16\%) [7]. This fact may be due to methodological differences, the time of the survey, and the phase of the epidemic curve in each country and the locally adopted preventative measures. It should be taken into consideration that in São Paulo, SP, at the time of the study, the Municipal Health Secretariat only allowed emergency clinical dental procedures at the SUS (Sistema Único de Saúde) public health network [13]. 
SARS-CoV-2 infection, in this study, was associated with the technical job category (DH and DA), in people with lower income, lower education level, and who used public transportation to commute to work. Thus, income inequalities can play an important role in the impact of COVID-19 in Brazil, through these contextual effects [14-16], even among health professionals.

The greater levels of SARS-CoV-2 infection among oral health professionals at the technical level, i.e., with lower levels of education, corroborate current findings [17-19]. The education level influences knowledge, behaviors, and appropriate practices related to preventing infection in the work environment and outside of it $[20,21]$. However, the work process in this context must also be considered: two people are recommended to reduce the amount of working time and the risk in the procedure. This increases the risk of similar aerosols. The technical team also washes and sterilizes the materials and cleans the room [9]. Thus, they can be more prone to SARS-CoV-2 infection [22-24].

The use of public transportation like the bus, train, and metro was associated with SARS-CoV-2 infection. Thus the method of transportation becomes a work factor as important as the clinic environment itself. In this sense, health services need to rethink their professionals' methods of transportation, which put their own health and that of their colleagues and users at risk. Different from the health services that adopted the use of PPE and strict biosafety protocols [4-7] to reduce the risks of infection, the precautions taken on public transportation depend on the actions of public entities and the adherence of the users [25,26]. This fact is further compounded in studies done in a cosmopolitan city like São Paulo.

As found in the literature [13,24-27], the health professionals feel informed about COVID-19; they have access to the necessary PPE and evaluated it as being of good quality. However, they showed a high prevalence of feeling unsafe, afraid, and anxious about the risk of infection, as shown in other studies [21,23]. This factor can explain the high levels of adherence to adopting preventative measures, for example, the use and a more careful removal of PPE, which culminates in the decrease of infection [20,21,28].

Regarding limitations, this study excluded people who were on leave, which could have excluded people with symptoms and no diagnosis. However, it should be highlighted that all the participants of this study are on strategic family health teams working in public health clinics, explaining why they work 40 hours per week and receive good salaries as compared to other Brazilian cities. This is why they nearly always work exclusively at this job, which can reduce the understanding about the possibility of infection at other workplaces.

\section{Conclusion}

The prevalence of SARS-CoV-2 was high among oral health professionals in primary health care (PHC) and was associated with sociodemographic factors, such as a lower salary and education level, and work factors, such as the category of technical professional and the use of public transportation. The professionals showed a high prevalence of ongoing education, mainly e-learning, and the availability of high-quality PPE. In spite of feeling prepared for the work process during the COVID-19 pandemic, they felt unsafe, afraid, and anxious about the risk of infection.

\section{Authors' Contributions}

\begin{tabular}{|c|c|c|}
\hline JPN & https://orcid.org/0000-0002-6988-5826 & $\begin{array}{l}\text { Conceptualization, Methodology, Formal Analysis, Investigation, Data Curation, Writing - } \\
\text { Original Draft and Writing - Review and Editing. }\end{array}$ \\
\hline MFS & https://orcid.org/0000-0002-3599-5947 & Conceptualization, Methodology and Writing - Original Draft. \\
\hline AMCB & https://orcid.org/0000-0002-7302-6880 & Conceptualization, Methodology and Writing - Original Draft. \\
\hline LLM & https://orcid.org/0000-0003-3951-3607 & Conceptualization, Methodology and Writing - Original Draft. \\
\hline
\end{tabular}


WB (D) https://orcid.org/0000-0001-6124-5771 Conceptualization, Methodology and Writing - Review and Editing.

DCP (iD) https://orcid.org/0000-0003-4184-4464 Writing - Review and Editing.

$\mathrm{DB}$ (iD) https://orcid.org/0000-0003-0591-0495 Writing - Review and Editing.

CNM (iD https://orcid.org/0000-0002-0121-0398 Writing - Review and Editing.

ACNM (iD https://orcid.org/0000-0001-9004-7176 Conceptualization, Methodology and Writing - Review and Editing.

MFSJ (i) https://orcid.org/0000-0001-8837-5912 Methodology, Formal Analysis and Writing - Review and Editing.

All authors declare that they contributed to critical review of intellectual content and approval of the final version to be published.

\section{Financial Support}

None.

\section{Conflict of Interest}

The authors declare no conflicts of interest.

\section{Data Availability}

The data used to support the findings of this study can be made available upon request to the corresponding author.

\section{References}

[1] Mallineni SK, Innes NP, Raggio DP, Araujo MP, Robertson MD, Jayaraman J. Coronavirus disease (COVID-19): Characteristics in children and considerations for dentists providing their care. Int J Paediatr Dent 2020; 30(3):24550. https://doi.org/10.1111/ipd.12653

[2] Correia MITD, Ramos RF, Bahten LCV. The surgeons and the COVID-19 pandemic. Rev Col Bras Cir 2020; 47:e20202536. https://doi.org/10.1590/0100-6991e-20202536

[3] Meng L, Hua F, Bian Z. Coronavirus disease 2019 (COVID-19): Emerging and future challenges for dental and oral medicine. J Dent Res 2020; 99(5):481-7. https://doi.org/10.1177/0022034520914246

[4] Ather A, Patel B, Ruparel NB, Diogenes A, Hargreaves KM. Coronavirus Disease 19 (COVID-19): Implications for clinical dental care. J Endod 2020; 46(5):584-95. https://doi.org/10.1016/j.joen.2020.03.008

[5] Izzetti R, Nisi M, Gabriele M, Graziani F. COVID-19 Transmission in dental practice: brief review of preventive measures in Italy. J Dent Res 2020; 99(9):1030-8. https://doi.org/10.1177/0022034520920580

[6] Peng X, Xu X, Li Y, Cheng L, Zhou X, Ren B. Transmission routes of 2019-nCoV and controls in dental practice. Int J Oral Sci 2020; 12(1):9. https://doi.org/10.1038/s41368-020-0075-9

[7] Estrich CG, Mikkelsen M, Morrissey R, Geisinger ML, Ioannidou E, Vujicic M, et al. Estimating COVID-19 prevalence and infection control practices among US dentists. J Am Dent Assoc 2020; 151(11):815-24. https://doi.org/10.1016/j.adaj.2020.09.005

[8] Selvati FS, Teixeira LGF, Loureiro LH, Pereira RMS. Covid-19 control strategies in Brazil: what the pandemic teaches us?. Res Soc Develop 2020; 9(8):e664986293. https://doi.org/10.33448/rsd-v9i8.6293

[9] Brasil. Gerência de Vigilância e Monitoramento em Serviços de Saúde. ANVISA. Nota Técnica GVIMS/GGTES/ANVISA nº4/2020 de 31 de março de 2020. Orientações para Serviços de Saúde: Medidas de Prevenção e Controle que Devem Ser Adotadas durante a Assistência aos Casos Suspeitos ou Confirmados de Infecção pelo Novo Coronavírus. Available from: <http://portal.anvisa.gov.br/documents/33852/271858/Nota+T\%C3\%A9cnica+n+04-2020+GVIMS-GGTESANVISA/ab598660-3de4-4f14-8e6f-b9341c196b28>. [Accessed on April 26, 2020]. [In Portuguese].

[10] Prefeitura do Município de São Paulo. Coordenação de Atenção à Saúde. Departamento de Atenção Básica. Recomendações para a Rede Básica Municipal de Saúde frente a pandemia de Coronavirus (COVID-19). 2020. Available from: https://www.prefeitura.sp.gov.br/cidade/secretarias/upload/saude/RECOMENDAOES_PARA_A_REDE_BASIC A_MUNICIPAL_DE_SAUDE.pdf. [Accessed on April 26, 2020]. [In Portuguese].

[11] Gaspar GS, Figueiredo N, Lucena EHG, Ceissler CAS, Cavalcanti RP, Goes PSA. Characterization of dental surgeons of Pernambuco state in the COVID-19 pandemic context: preliminary data. Pesqui Bras Odontopediatria Clín Integr 2020; 20(Suppl 1):e0145. https://doi.org/10.1590/pboci.2020.152

[12] Alobuia WM, Dalva-Baird NP, Forrester JD, Bendavid E, Bhattacharya J, Kebebew E. Racial disparities in knowledge, attitudes and practices related to COVID-19 in the USA. J Public Health 2020; 42(3):470-8. https://doi.org/10.1093/pubmed/fdaa069

[13] Bontà G, Campus G, Cagetti MG. COVID-19 pandemic and dental hygienists in Italy: a questionnaire survey. BMC Health Serv Res 2020; 20(1):994. https://doi.org/10.1186/s 12913-020-05842-x

[14] Cagetti MG, Cairoli JL, Senna A, Campus G. COVID-19 outbreak in North Italy: an overview on dentistry. A questionnaire survey. Int J Environ Res Public Health 2020; 17(11):3835. https://doi.org/10.3390/ijerph17113835

[15] Demenech LM, Dumith SC, Vieira MECD, Neiva-Silva L. Income inequality and risk of infection and death by COVID-19 in Brazil. Rev Bras Epidemiol 2020; 23:e200095. https://doi.org/10.1590/1980-549720200095 
[16] Raifman MA, Raifman JR. Disparities in the population at risk of severe illness from COVID-19 by race/ethnicity and income. Am J Prev Med 2020; 59(1):137-9. https://doi.org/10.1016/j.amepre.2020.04.003.

[17] Palacio A, Tamariz L. Social determinants of health mediate COVID-19 disparities in South Florida. J Gen Intern Med 2021; 36(2):472-7. https://doi.org/10.1007/s11606-020-06341-9

[18] Wake AD. Knowledge, attitude, practice, and associated factors regarding the novel coronavirus disease 2019 (COVID-19) pandemic. Infect Drug Resist 2020; 13:3817-32. https://doi.org/10.2 147/IDR.S275689

[19] Wiemers EE, Abrahams S, AlFakhri M, Hotz VJ, Schoeni RF, Seltzer JA. Disparities in vulnerability to complications from COVID-19 arising from disparities in preexisting conditions in the United States. Res Soc Stratif Mobil 2020; 69:100553. https://doi.org/10.1016/j.rssm.2020.100553

[20] Alobuia WM, Dalva-Baird NP, Forrester JD, Bendavid E, Bhattacharya J, Kebebew E. Racial disparities in knowledge, attitudes and practices related to COVID-19 in the USA. J Public Health 2020; 42(3):470-8. https://doi.org/10.1093/pubmed/fdaa069

[21] Zhang M, Zhou M, Tang F, Wang Y, Nie H, Zhang L, et al. Knowledge, attitude, and practice regarding COVID-19 among healthcare workers in Henan, China. J Hosp Infect 2020; 105(2):183-7. https://doi.org/10.1016/j.jhin.2020.04.012

[22] Bruine de Bruin W, Bennett D. Relationships between initial COVID-19 risk perceptions and protective health behaviors: a national survey. Am J Prev Med 2020; 59(2):157-67. https://doi.org/10.1016/j.amepre.2020.05.001

[23] Rader B, Scarpino SV, Nande A, Hill AL, Adlam B, Reiner RC, et al. Crowding and the shape of COVID-19 epidemics. Nat Med 2020; 26(12):1829-34. https://doi.org/10.1038/s41591-020-1 104-0

[24] Morawska L, Tang JW, Bahnfleth W, Bluyssen PM, Boerstra A, Buonanno G, et al. How can airborne transmission of COVID-19 indoors be minimised? Environ Int 2020; 142:105832. https://doi.org/10.1016/j.envint.2020.105832

[25] Ahmed MA, Jouhar R, Ahmed N, Adnan S, Aftab M, Zafar MS, et al. Fear and practice modifications among dentists to combat novel coronavirus disease (COVID-19) outbreak. Int J Environ Res Public Health 2020; 17(8):2821. https://doi.org/10.3390/ijerph 17082821

[26] Silva R, Zermiani T, Bonan K, Ditterich R. Clinical dental protocols during the COVID-19 pandemic in Mercosur countries: similarities and discrepancies. Vigil Sanit Debate 2020, 8(3):86-93. https://doi.org/10.22239/2317-269x.01620

[27] Lima YO, Costa DM, Sousa JM. Risco por ocupação. 2021. Available from: https://impactocovid.com.br/. [Accessed on January 23, 2021]. [In Portuguese].

[28] Ren Y, Feng C, Rasubala L, Malmstrom H, Eliav E. Risk for dental healthcare professionals during the COVID-19 global pandemic: An evidence-based assessment. J Dent 2020; 101:103434. https://doi.org/10.1016/j.jdent.2020.103434 